\title{
Migration delays and mortality of adult Atlantic salmon Salmo salar en route to spawning grounds on the River Allier, France
}

\author{
Aurore Baisez ${ }^{1}$, Jean-Michel Bach ${ }^{1}$, Cédric Leon ${ }^{1}$, Thimothé Parouty ${ }^{1}$, \\ Renaud Terrade $^{2}$, Marion Hoffmann ${ }^{1}$, Pascal Laffaille ${ }^{2, *}$ \\ ${ }^{1}$ Logrami, 8 rue de la Ronde, 03500 Saint-Pouçain sur Sioule, France \\ ${ }^{2}$ Université de Toulouse; INP, UPS, CNRS; EcoLab (Laboratoire Ecologie Fonctionnelle et Environnement); ENSAT, \\ Avenue de l'Agrobiopole, 31326 Castanet Tolosan, France
}

\begin{abstract}
During summer periods when water temperatures are high, Atlantic salmon Salmo salar are forced to halt their migration. This phenomenon was observed in our study in the River Allier in France. Between 200 and 1200 S. salar have come to spawn in the River Allier every year for the last 2 decades, but the population has suffered a severe decline. In 2009, 30 individuals were radio tracked; of these, 11 died during the summer period, while the other 19 resumed their migration in the fall. This mortality level was higher amongst the $S$. salar that arrived towards the end of the migration period, i.e. those individuals that tended to spend the summer in the lower, warmer stretch of the river. In view of the continuing rise in freshwater temperatures, measures are urgently needed to reduce the impact of increased temperatures on fish in the River Allier. This could be achieved by (1) promoting summer delays further upstream by making it easier for fish to pass through dams and (2) by protecting the spawning adults, particularly in the locations of summer halt. This study is consistent with a growing body of literature that suggests that climate change could have devastating effects on the upstream migration phase of anadromous salmonids.
\end{abstract}

KEY WORDS: Management $\cdot$ Water temperature $\cdot$ Climate change $\cdot$ Long river

\section{INTRODUCTION}

Atlantic salmon Salmo salar L. occur naturally along both the east and west coasts of the North Atlantic Ocean where they exist in both anadromous and non-anadromous freshwater resident forms, although most are anadromous. S. salar is one of the diadromous species that travel several hundred kilometers to spawn in the upstream reaches of watercourses after growing for 1, 2, or $3 \mathrm{yr}$ in the sea (Klemetsen et al. 2003). The distribution of Atlantic salmon populations in Europe and North America indicates that in many rivers that have historically supported Atlantic salmon populations, populations have been ex- tirpated or have experienced severe declines. The severe decline of $S$. salar throughout its entire distribution over the last 3 decades, despite numerous management and conservation programs, is an alarming indication of the vulnerability of this species. Consequently, $S$. salar is now considered to be a threatened species in some regions (Parrish et al. 1998). This reduced abundance is associated with numerous anthropogenic factors, such as acid rain, hydroelectric development, overexploitation, parasitic infections, and interactions with farmed $S$. salar (Parrish et al. 1998, Laffaille 2011).

Elevated water temperatures associated with climate change have also had negative impacts on 
Salmo salar (Jonsson \& Jonsson 2009). S. salar is a coldwater species that spawns in the fall and requires a high level of dissolved oxygen to do so. There is a high risk that a further rise in temperature in the near future could lead to the loss of populations, particularly in the southernmost areas of their range, with the greatest risk faced by small populations (Bürger \& Lynch 1995). If the water temperature rises too high in major watercourses, migrating salmonids have to halt (i.e. stop moving upstream) during the summer, when possible in cool-water refuges, if they are to successfully complete long migrations and go on to spawn (Crozier et al. 2008). Extreme temperatures can have an effect on the timing of the upstream migration due to selection against migration during stressful temperature conditions, because warm temperatures reduce the scope for aerobic activity and thus swimming performance (Lee et al. 2003). Moreover, when the temperature-dependent metabolic costs are high, energy reserves are quickly exhausted (Glebe \& Leggett 1981). This happens in the case of $S$. salar in the River Loire (France), which is one of the longest river systems in Europe in which spawning migration occurs (Cuinat 1988). Some of the tributaries of the Loire (particularly the Allier, the largest upstream tributary) harbor natural populations of $S$. salar. In order to reach the nearest potential spawning grounds, $S$. salar must travel at least $765 \mathrm{~km}$ from the sea, and pass through 16 dams ( 7 on the Loire, including 3 supplying nuclear power stations, and 9 on the Allier).

The last 3 decades have seen the widespread use of radiotracking to monitor salmon migrations (Croze et al. 2008, Keefer et al. 2008). This method makes it possible to track the movements and activity of fish in real time. In light of what we know about the impact of temperature increase on summer mortality amongst salmon (see Jonsson \& Jonsson 2009), the main objective of the present study was to estimate the summer mortality of adults during their spawning migration in the Allier River by means of radio telemetry. We tracked the fate of 30 Salmo salar individuals fitted with transmitters and we evaluated predictive factors with regard to mortality based on temperature, migration timing, and location. Tracking efforts focused on summer periods.

\section{MATERIALS AND METHODS}

\section{Study area}

The Loire is the longest French river. It is $1012 \mathrm{~km}$ long, and its catchment area of $117000 \mathrm{~km}^{2}$ occupies more than one-fifth of the land area of France (Fig. 1). The main axis of the basin (i.e. the Loire River and its main tributary, the Allier River) is subjected to little regulation and displays good longitudinal connectivity compared to the other tributaries (including some fairly large rivers) that are substantially impounded (Laffaille et al. 2009). However, the Loire basin is often considered to be less impacted than other large river systems in Europe (Lasne et al. 2007). The first obstacle on the main watercourse is only encountered $330 \mathrm{~km}$ upstream from the estuary (the Saint Laurent des Eaux dam). The Allier is the main direct tributary of the Loire, and is where the most functional Salmo salar spawning zones are found. After draining a $14310 \mathrm{~km}^{2}$ catchment area parallel to the Upper Loire, the Allier flows into the Loire at the Bec d'Allier, about $421 \mathrm{~km}$ from its source. The Allier has been divided into 3 main segments (Cuinat 1988). The Upper Allier is characterized by a steeply enclosed valley (known as the Allier Gorges), which varies in width from 10 to $30 \mathrm{~m}$, and has a slope of $0.7 \%$. The mean water temperature in this segment is between 0 and $5^{\circ} \mathrm{C}$ in the winter, and rarely

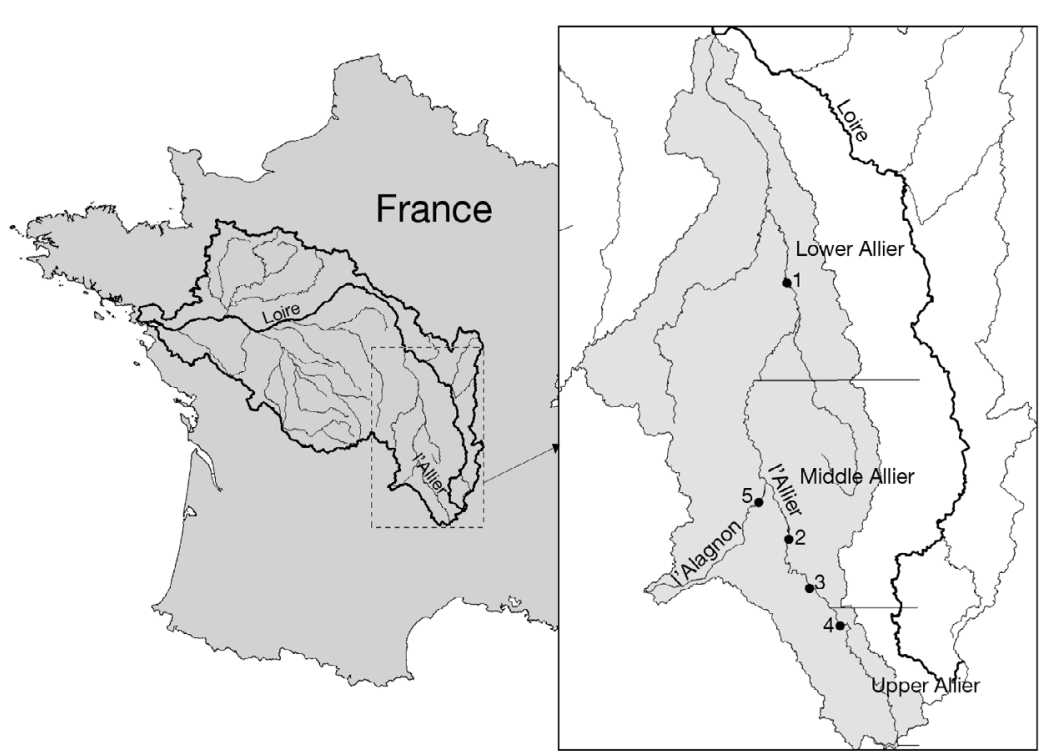

Fig. 1. Locations of the Loire, the Allier, the Alagnon, and (right panel) the hydraulic installations at Vichy (1), Vieille Brioude (2), Langeac (3), Poutès (4), and Lempdes (5) 
exceeds $20^{\circ} \mathrm{C}$ in the summer. The river then gradually widens, reaching 40 to $80 \mathrm{~m}$ in the Middle Allier where it has a mean summer temperature of $21^{\circ} \mathrm{C}$, and can sometimes exceed $25^{\circ} \mathrm{C}$. Finally, the Lower Allier, (known as the Allier des Plaines) starts around the Pont du Château, with an extensive alluvial plain (2 to $3 \mathrm{~km}$ ) with a very gentle slope $(0.07 \%)$. It is about $100 \mathrm{~m}$ wide; pebble substrates gradually give way to sand, and its summer temperature regularly reaches $22^{\circ} \mathrm{C}$, and exceeds $26^{\circ} \mathrm{C}$ on average on $10 \mathrm{~d}$ each year.

\section{Tracking methods}

An operation intended to trap and mark Salmo salar during their spawning migration was carried out at the fish pass of the Vichy dam (the fish must pass through this dam to spawn, see www. logrami.fr). This operation began on 27 March 2009 and was completed on 5 May 2009 (i.e. 39 d), yielding a sample of 30 fish representative of the spring migrating population. The length of each fish was measured at the video-counting station of the Vichy dam. The size structure of the captured and noncaptured fish were compared and analyzed by a $\chi^{2}$ test. Fish were gastrically tagged with radio transmitters following anesthetization using a solution of clove oil at 28 to $40 \mathrm{ppm}$, depending on ambient water temperature in well-aerated river water (see Croze et al. 2008). The fish stop feeding as soon as they enter fresh water, and the stomach shrinks as the fish travels upstream, which makes it possible to ensure that the transmitter remains in place as long as it is not regurgitated just after being inserted. After tagging, the fish were placed in a dark, oxygenated recovery tank for 30 to $60 \mathrm{~min}$ and were released where they had been caught via the upstream trap of the recovery tank. The radio transmitters used (Advanced Telemetry System, ATS; $50 \mathrm{~mm} \times 19 \mathrm{~mm}$; weight in air: $24 \mathrm{~g}$, yielding tag to body mass ratios of less than $2 \%$; Bridger \& Booth 2003), emitted at a range of frequencies of between 48 and $49.9 \mathrm{MHz}$, and their autonomy (about $430 \mathrm{~d}$ ) made it possible to cover the entire study (until the $S$. salar spawned in winter).

The receivers used to detect the fish were also supplied by ATS (model R2100) and were equipped with an automatic scanner and data-logger. Initially, a rapid scan was carried out from a vehicle beside the watercourses, using a receiver connected to a whip aerial antenna. A local search was then carried out on foot, using the biangulation method either with a loop aerial antenna connected to the receiver, or with an immersed loop antenna to provide a more precise location.

All 30 Salmo salar delayed their migration during the summer period. We characterized this delay for each fish in terms of the start and end dates, the duration, and the location and mean water temperature during the halt. The temperature $\left({ }^{\circ} \mathrm{C}\right)$ during the summer delay was recorded every hour using temperature probes at the levels of Vichy (representative of the Lower Allier), Vieille Brioude (representative of the Middle Allier), and Poutès (representative of the Upper Allier) on the Allier, and at Lempdes on the Alagnon (the main tributary of the Allier flowing into the Middle Allier; Fig. 1). These measurements were obtained throughout the summer.

\section{Statistical analysis}

We used logistic regressions (McCullagh \& Nelder 1989) to test the date (day of year) when the fish were marked, the location of the summer delay site $(\mathrm{km}$ from Vichy), and the mean temperature during the delay $\left({ }^{\circ} \mathrm{C}\right)$ as the independent variables, and survival (yes/no) as the dependent variable. We also tested interactions between variables. Following Burnham \& Anderson (2002), we used the Akaike Information Criterion (AIC $=2 \times \log$-likelihood $+2 n$, where $n$ is the number of parameters estimated) to select the best models. The correlations were determined between the location of the summer delay site $(\mathrm{km}$ from Vichy), the date (day of year) when the fish were marked, and the mean temperature during the halt (Spearman's test). Finally, a Mann-Whitney test was carried out to determine whether the mean temperature experienced during the summer halt by the individuals that resumed their migration in the fall was significantly different from that experienced by those that died during the summer.

\section{RESULTS}

Between 27 February and 25 October 2009, 491 Salmo salar passed through the Vichy dam; of these, 359 were recorded between 27 March and 5 May. The size of the 30 fish caught and tagged ranged from 76 to $103 \mathrm{~cm}$, with a mean $( \pm$ SD) size of $92 \pm$ $7.9 \mathrm{~cm}$, which corresponds to individuals that have spent 2 or 3 yr living at sea, according to the estimations of Baglinière et al. (1985). There was no significant difference in the distribution of the fish by size 
class between the untagged salmon observed at Vichy and those that were tagged $\left(\chi^{2}\right.$ test: $\chi^{2}=0.930$; $\mathrm{p}=0.818$ ).

The date when the summer delay began for the tagged fish ranged from 9 May to 22 June 2009 (i.e. a period of $1.5 \mathrm{mo}$ ). Eleven of the marked fish died during the summer. The surviving Salmo salar resumed their migration between 5 and 22 October (i.e. with no more than $17 \mathrm{~d}$ between the earliest and the latest departures) before going on to spawn further upstream. The selected model based on the AIC showed that the date when the fish were marked, the location of the summer delay site, the mean temperature during the delay, and the interactions between these variables had a significant effect on their survival $\left(\chi^{2}, \mathrm{p}<0.001\right.$; AIC $\left.=30.50\right)$.

The most downstream summer delay site observed was $40.8 \mathrm{~km}$ upstream from Vichy, and the most upstream was $195 \mathrm{~km}$ from Vichy, between the Langeac and Poutès dams. During the summer, the fish were therefore distributed over more than $150 \mathrm{~km}$ in the Allier, out of the potential $276 \mathrm{~km}$ corresponding to the total length of the water course available upstream from Vichy. We found a significant relationship between the date when the individuals reached Vichy, and where they had been delayed (Spearman's test; $r=-0.649 ; p<0.001$ ). We can distinguish 3 different zones, with decreasing mortality from the downstream Allier (of the 9 fish that had halted in the lower Allier, $56 \%$ died during the summer), through the Middle Allier (38\% of the 13 fish that had delayed in the middle Allier died during the summer) to the upstream Allier (where 13\% of the 8 fish that had delayed in the upper Allier died during the summer).

The Salmo salar stopped their migration when the mean $( \pm \mathrm{SD})$ daily temperature of the water reached $15.5 \pm 2.7^{\circ} \mathrm{C}$, with a maximum recorded temperature of $22.6^{\circ} \mathrm{C}$ and a minimum of $11.2^{\circ} \mathrm{C}$. The mean daily temperature during the summer delay (from $20.8 \pm$ $2.7^{\circ} \mathrm{C}$ with a maximum of $26.3^{\circ} \mathrm{C}$ downstream, and $17.7 \pm 2.6^{\circ} \mathrm{C}$ with a maximum of $22.5^{\circ} \mathrm{C}$ upstream) was statistically correlated with the different delay sites (Spearman's test $; r=-0.682 ; p<0.001$ ), and the date when the fish were marked (Spearman's test; $r=$ $0.736 ; \mathrm{p}<0.001)$. Finally, the $S$. salar that survived the summer period were exposed to a mean temperature of $18.9^{\circ} \mathrm{C}\left( \pm 0.9^{\circ} \mathrm{C}\right)$ during their delay, which was significantly lower (Mann-Whitney test; $U=15$; $\mathrm{p}<0.001)$ than that experienced by those that died (mean temperature of $20.4 \pm 0.7^{\circ} \mathrm{C}$ ). Thus, the later the $S$. salar reached Vichy, the less chance they had of surviving the summer conditions.

\section{DISCUSSION}

Water temperature plays a key role in migration, affecting fish activity and metabolism (Beitinger \& Fitzpatrick 1979), swimming abilities (Wardle 1980), and migration rate (Quinn et al. 1997). Extreme temperatures can even lead to a suspension of migration during the upstream migration (Alabaster 1990). Migrating salmonids have to halt their upstream journey in the summer when the environmental conditions are no longer suitable for migration towards the spawning zones (Shepard 1995, Keefer et al. 2008). Thioulouse (1972) and Shepard (1995) demonstrated the decisive role of extremes of water temperature (below $6^{\circ} \mathrm{C}$ and above $20^{\circ} \mathrm{C}$ ) as a factor triggering the delay of Salmo salar migration. However, our results indicate that some fish stopped their migration and delayed at temperatures of less than $20^{\circ} \mathrm{C}$. In fact, in our study, the average temperature when the fish delayed upstream migration was $15.5^{\circ} \mathrm{C}$, with some fish delaying at temperatures as low as $11^{\circ} \mathrm{C}$. These temperatures are not unfavorable for salmon migration, and so other environmental factors must directly or indirectly trigger delays and resumption of migration. The river flow rate is certainly one of these factors, and is widely cited as an environmental factor controlling the anadromous migration of salmon (Jensen et al. 1986, Trépanier et al. 1996). During a similar preliminary study in 2006 (Bach et al. 2008), summer delays were observed to start between 17 May and 21 June. Delays therefore occurred earlier in 2009 for some individuals, and extended over a longer period. In fall 2006 migration was resumed on 25 September, i.e. nearly 1 mo earlier than in 2009. This difference is attributable to the earlier increase in water flow observed in 2006.

As Keefer et al. (2008) found for Oncorhynchus nerka (Walbaum), our findings are pessimistic with regard to the high levels of adult mortality during spawning. Our study does indeed reveal high summer mortality, since in 2009 , on average $37 \%$ of the Salmo salar upstream of Vichy did not survive the summer period. Mortality was particularly high amongst the stragglers that reached Vichy late and were forced to spend the summer relatively far downstream in the Lower Allier, in zones where the temperature is higher in summer. In 2009, mortality levels in the Lower Allier were very high (56\%).

Fish are poikilothermic organisms and can survive only in a certain range of temperatures. Different authors have reported differing lethal temperature values for adults. Alabaster \& Lloyd (1982) indicated that for various different species of the genus Salmo living in rivers with a summer temperature naturally 
of the order of 20 to $21^{\circ} \mathrm{C}$, any increase above these values may be damaging. The threshold for mortality in S. salar is about $23^{\circ} \mathrm{C}$ (Shepard 1995), although according to some other authors it could exceed $27^{\circ} \mathrm{C}$, and even be as high as 29 to $30^{\circ} \mathrm{C}$ (Mills 1989). This value is mainly dependent on the acclimation of the fish and the duration of exposure (Shepard 1995). In salmonids, the direct effects of elevated temperatures are associated with increased metabolic demands that exhaust their energy reserves (Glebe \& Leggett 1981), and may be exacerbated by other factors, including reduced disease resistance and increased susceptibility to disease (Cairns et al. 2005). Temperatures in the range of 20 to $27^{\circ} \mathrm{C}$ reduce resistance to disease, and thus may be indirectly lethal for S. salar (Danie et al. 1984). An increase in temperature may also reduce the concentrations of toxic substances tolerated by salmon, as in the case of heavy metals (Alabaster \& Lloyd 1982). Finally, the eutrophication of rivers due to an increase in temperature can affect salmon populations in situ, as was the case on the River Wye, in Wales, during the summer of 1976 (Brooker et al. 1977). Thus, high temperatures, even below values that are usually lethal, can contribute to mortality during the spawning migration of salmonids. This was also observed in 2006, when 27 out of the 31 fish caught at Vichy did not survive the summer period, i.e. $90 \%$ mortality (Bach et al. 2008). This high mortality rate in 2006 may be explained by the fact that the marking and tracking had involved spawning adults at the end of the spring migration, individuals which had inevitably had to delay for the summer in the downstream reaches, at summer temperatures which were even higher in 2006 than in 2009. We cannot avoid wondering what happened to the fish that had not reached Vichy before delaying for the summer, and amongst which mortality must have been very high, because summer temperatures are higher downstream of the Vichy dam. Indeed, with the exception of the year $2002(20 \%$ of passages occurred after 1 June), very few fish reached Vichy (measured at the video-counting station) after 1 June (a mean of $5 \%$ of the fish tracked between 1997 and 2010), and virtually none in the fall after the summer halt (Logrami unpublished data).

Increasing numbers of studies have investigated the challenges facing diadromous salmonids resulting from climate change (Crozier et al. 2008). Jonsson \& Jonsson (2009) pointed out the extent to which salmonids are subjected to changes in the environmental conditions, notably water temperature and flow. For example, changes in arrival dates (both the dates of the first captures and the median capture dates have shifted significantly earlier by about $0.5 \mathrm{~d}$ $\mathrm{yr}^{-1}$ over the last $23 \mathrm{yr}$ ) have already been observed for Salmo salar in the Connecticut River drainage (the southernmost extent of the species' North American range) related to changes in these environmental parameters, and notably in the temperature (Juanes et al. 2004). Gosse et al. (2008) published an analysis of the mean summer temperature of the Loire during the period 1949 to 2003. Over this period, warming of the water by $2^{\circ} \mathrm{C}$ was observed about $75 \mathrm{~km}$ downstream of the Bec d'Allier. If we consider that temperature is the main factor explaining fish mortality during the summer, the $2^{\circ} \mathrm{C}$ rise observed in the Loire is clearly crucial. Our study revealed that a rise of just $1.5^{\circ} \mathrm{C}$ (the mean difference between the upstream and downstream zones of the Allier) is sufficient to produce a marked increase in summer mortality. It is therefore important to find out why this increase in the water temperature is occurring (climate change and/or the discharge of cooling water from nuclear power stations and/or the damming of water further upstream?) and to evaluate potential engineering-based technical solutions. The combined effects of obstacles, even if fish passes make it possible for the fish to get beyond them, is to further delay migration (Croze et al. 2008). It therefore appears essential to improve habitat accessibility (i.e. to make it easier for $S$. Salar to get past the obstacles located in the downstream reaches), so that they progress as far upstream as possible before delaying for the summer. One way to restore diadromous populations is to optimize the design of hydraulic systems in order to facilitate access to the species' preferred and functional habitats (Laffaille et al. 2009). It also seems to be very important to protect the spawning adults that arrive first, so that they can spawn naturally as far upstream as possible, in the best spawning grounds, located upstream of the Poutès dam on the Allier and in the Alagnon. To do this, it is also necessary to prevent the elimination of these individuals (by poaching or the removal of spawning adults for artificial spawning in fish farms).

Acknowledgements. We thank C. Renoux and P. Portafaix (Logrami) for their assistance in collecting data in 2009, and M. Lelievre (Fédération de Pêche et de Protection des Milieux Aquatiques de l'Allier) for reading a draft text. We also thank our funding organizations: l'Agence de l'Eau Loire-Bretagne, l'Europe (Fonds Européens de Développement Régional), la Fédération Nationale de la Pêche en France, la Région Bourgogne and la Région Poitou-Charentes. Finally, we thank the reviewers and the responsible editor (S. Cooke) for their valuable comments on an earlier version of the manuscript. 


\section{LITERATURE CITED}

Alabaster JS (1990) The temperature requirements of adult Atlantic salmon Salmo salar L. during their upstream migration in the river Dee. J Fish Biol 37:659-661

Alabaster JS, Lloyd R (1982) Water quality criteria for freshwater fish. Butterworth Scientific, London

Bach JM, Lelievre M, Trotet M (2008) Evaluation de la libre circulation sur l'axe Loire Allier. Suivi par radiopistage de la migration anadrome du saumon atlantique en 2006. Research Technical Report of Logrami. Logrami, SaintPouçain sur Sioule

Baglinière JL, Bomassi P, Bousquet B, Chancerel F and others (1985) La détermination de l'âge par scalimétrie chez le saumon atlantique (Salmo salar) dans son aire de répartition méridionale: utilisation pratique et difficultés de la méthode. Bull Fr Peche Piscic 298:69-105

Beitinger TL, Fitzpatrick LC (1979) Physiological and ecological correlates of preferred temperature in fish. Am Zool 19:319-329

Bridger CJ, Booth RK (2003) The effects of biotelemetry transmitter presence and attachment procedures on fish physiology and behaviour. Rev Fish Sci 11:13-34

Brooker MP, Morris DL, Hemsworth RJ (1977) Mass mortalities of adult salmon, Salmo salar, in the R. Wye, 1976. J Appl Ecol 14:409-417

Bürger R, Lynch M (1995) Evolution and extinction in a changing environment: a quantitative-genetic analysis. Evolution 49:151-163

Burnham KP, Anderson DR (2002) Model selection and multimodel inference: a practical information-theoretic approach, 2nd edn. Springer Verlag, New York, NY

> Cairns MA, Ebersole JL, Baker JP, Wigington PJ, Lavigne HR, Davis SM (2005) Influence of summer stream temperatures on black spot infestation of juvenile coho salmon in the Oregon Coast range. Trans Am Fish Soc 134:1471-1479

> Croze O, Bau F, Delmouly L (2008) Efficiency of a fish lift for returning Atlantic salmon at a large-scale hydroelectric complex in France. Fish Manag Ecol 15:467-476

Crozier LG, Hendry AP, Lawson PW, Quinn TP and others (2008) Potential responses to climate change in organisms with complex life histories: evolution and plasticity in Pacific salmon. Evol Appl 1:252-270

Cuinat R (1988) Atlantic salmon in an extensive French river system: the Loire-Allier. In: Mills D, Piggins D (eds) Atlantic salmon: planning for the future. Croom Helm, London, p 389-399

Danie DS, Trial JG, Stanley JG (1984) Species profiles: life histories and environmental requirements of coastal fish and invertebrates (North Atlantic): Atlantic salmon. US Fish and Wildlife Service, University of Maine, Orono, $\mathrm{ME}$

Glebe BD, Leggett WC (1981) Temporal, intra-population differences in energy allocation and use by American shad (Alosa sapidissima) during the spawning migration. Can J Fish Aquat Sci 38:795-805

Gosse P, Gailhard J, Hendrickx F (2008) Analyse de la température de la Loire moyenne en été sur la période 1949 à 2003. Hydroécol Appl 16:233-274

> Jensen AJ, Heggberget TG, Johnsen BO (1986) Upstream migration of adult Atlantic salmon, Salmo salar L., in the River Vefsna, northern Norway. J Fish Biol 29: 459-465

Jonsson B, Jonsson N (2009) A review of the likely effects of climate change on anadromous Atlantic salmon Salmo salar and brown trout Salmo trutta, with particular reference to water temperature and flow. J Fish Biol 75: 2381-2447

> Juanes F, Gephard S, Beland K (2004) Long-term changes in migration timing of adult Atlantic salmon (Salmo salar) at the southern edge of the species distribution. Can J Fish Aquat Sci 61:2392-2400

> Keefer ML, Peery CA, Heinrich MJ (2008) Temperaturemediated en route migration mortality and travel rates of endangered Snake River sockeye salmon. Ecol Freshw Fish 17:136-145

Klemetsen A, Amundsen PA, Dempson JB, Jonsson B, Jonsson N, O'Connell MF, Mortensen E (2003) Atlantic salmon Salmo salar L., brown trout Salmo trutta L. and Arctic charr Salvelinus alpinus (L.): a review of aspects of their life histories. Ecol Freshw Fish 12:1-59

Laffaille P (2011) Impact of stocked Atlantic salmon (Salmo salar L.) on habitat use by the wild population. Ecol Freshw Fish 20:67-73

Laffaille P, Lasne E, Baisez A (2009) Effects of improving longitudinal connectivity on colonisation and distribution of European eel in the Loire catchment, France. Ecol Freshw Fish 18:610-619

> Lasne E, Bergerot B, Lek S, Laffaille P (2007) Fish zonation and indicator species for the evaluation of the ecological status of rivers: example of the Loire basin (France). River Res Appl 23:877-890

> Lee CG, Farrell AP, Lotto A, MacNutt MJ, Hinch SG, Healey MC (2003) The effect of temperature on swimming performance and oxygen consumption in adult sockeye (Oncorhynchus nerka) and coho (O. kisutch) salmon stocks. J Exp Biol 206:3239-3251

McCullagh P, Nelder JA (1989) Generalized linear models. Chapman \& Hall, London

Mills D (1989) Ecology and management of Atlantic salmon. Chapman \& Hall, London

Parrish DL, Behnke RJ, Gephard SR, McCormick SD, Reeves GH (1998) Why aren't there more Atlantic salmon (Salmo salar)? Can J Fish Aquat Sci 55:281-287

Quinn TP, Hodgson S, Peven C (1997) Temperature, flow, and the migration of adult sockeye salmon (Oncorhynchus nerka) in the Columbia River. Can J Fish Aquat Sci 54:1349-1360

Shepard SL (1995) Atlantic salmon spawning migrations in the Penobscot River, Maine. Fishways, flows and high temperatures. MSc Thesis, University of Maine, Orono, $\mathrm{ME}$

Thioulouse G (1972) Le comportement du saumon. Essai d'éthologie du saumon de l'Allier. Plein Air Service, Clermont-Ferrand

Trépanier S, Rodriguez MA, Magnan P (1996) Spawning migrations in landlocked Atlantic salmon: time series modelling of river discharge and water temperature effects. J Fish Biol 48:925-936

Wardle CS (1980) Effects of temperature on the maximum swimming speed of fishes. In: Ali MA (ed) Environmental physiology of fishes. Plenum Press, New York, NY, p 519-531

Submitted: February 25, 2011; Accepted: September 16, 2011 Proofs received from author(s): November 18, 2011 